\title{
Pathogenic and morphological variability among the isolates of Fusarium udum (Butler) causing wilt of pigeonpea (Cajanus cajan)
}

\author{
Sanjeev Kumar* \\ Department of Plant Pathology, Office of Dean, Faculty of Agriculture, Jawaharlal Nehru \\ Krishi Vishwavidyalaya, Jabalpur (MP), India \\ Shambhu Roy \\ KVK Lakhisarai , Bihar Agricultural University, Sabour, Bhagalpur (Bihar), India \\ J. P. Upadhyay \\ Ex. Director Research Services, Rajendra Agriculture University, Pusa (Bihar), India \\ *Corresponding author. Email: sanjeevcoa@gmail.com
}

\section{Article Info}

https://doi.org/10.31018/

jans.v13i4.2802

Received: July 3, 2021

Revised: November 4, 2021

Accepted: November 8, 2021

\section{How to Cite}

Kumar, S. et al. (2021). Pathogenic and morphological variability among the isolates of Fusarium udum (Butler) causing wilt of pigeonpea (Cajanus cajan). Journal of Applied and Natural Science, 13(4), 1305 - 1309. https://doi.org/10.31018/jans.v13i4.2802

\begin{abstract}
Wilt is the most serious disease causing irreversible losses and lethal damage to the crop in Bihar, Jharkhand, Orissa and the West Bengal states of Eastern India. Because of the existence of high pathogen variability, management of the disease using resistant cultivars will be a challenging task. For breeding resistant varieties, knowledge of pathogen variability in the particular crop area is essential. In present study, fifteen isolates viz., Fu-9, Fu-10, Fu-27,Fu-32, Fu-42, Fu-49, Fu-63, Fu-72, Fu-73, Fu-74,Fu-75,Fu-84, Fu-86, Fu-87, Fu-97 of Fusarium udum obtained from wilt infected pigeonpea plants of Bihar, Jharkhand, Orissa and West Bengal of Eastern India were assessed for the phenotypic variation. The isolates exhibited considerable variations in cultural and morphological characters viz., radial growth, mycelial color, sporulation, size and shape of macroconidia. Pathogenic variability on soil inoculated pot grown plants of pigeonpea resulted in 12.0 to 57.1 percent wilt incidence. The isolates also exhibited significant variations in symptoms like drooping of shoots, latent period, timing of fungal invasion, vascular clogging, drooping of shoots, and wilt establishment etc. Based on the wilt incidence, the fifteen isolates were distinguished into pathogenic groups. Fu- 10, Fu-27, Fu-32 and Fu-49 were found highly pathogenic and predominantly causing the typical wilt symptoms of more than one $31 \%$ wilt incidence. The present study indicates the existence of variability among isolates of vascular wilt pathogen collected from Eastern region of India.
\end{abstract}

Keywords: Pigeonpea, Fusarium udum, Cultural, Morphological, Pathogenic variability

\section{INTRODUCTION}

Pigeonpea [Cajanus cajan (L.) Millspaugh] is the fifth prominent pulse crop in the world and the second most important pulse crop after chickpea in India. (Patel and Patel, 2012). More than 210 pathogens infect Pigeonpea (83 fungi, 4 bacteria, 19 viruses and mycoplasma and 104 nematodes) reported from 58 countries (Reddy et al., 1990; Nene et al., 1996). The major diseases that assume significant importance include wilt (Fusarium udum Butler), sterility mosaic (Pigeonpea sterility mosaic virus) and Phytophthora blight (Phytophthora drechsleri Tucker f. sp. cajani ( Kannaiyan et al. 1985 ). Among these, wilt is the most serious disease causing irreversible losses and lethal damage to the crop. The disease appears in the early stage of plant growth (Nene et al., 1979) as gradual or sudden withering and drying and causes serious yield losses, sometimes up to $100 \%$ in susceptible cultivars (Saxena et al., 2010). The pathogen can survive on infected plant debris in the soil for about three years (Kumar and Upadhyay,2014). A number of races/stains have been reported for this pathogen which differs in pathogenicity, host range, distribution and appearance in culture (Joshi, 2010; Kumar and Upadhyay, 2013). Although some landraces/varieties of pigeon pea have shown promise in resistance breeding programmes against the wilt of pigeon pea, there are no reports of immunity against this disease. Sources of resistance identified in one region do not perform with the same degree of resistance in other regions, indicating pathogenic variability in the fungus ( Kumar and Upadhyay,2020). The present study was undertaken to have an insight and identify pathogenic variability among isolates from dif- 
ferent pigeon pea growing areas of Bihar, Jharkhand, Orissa and West Bengal in relation to morphological and cultural characteristics.

\section{MATERIALS AND METHODS}

\section{Survey and collection of wilted plant samples}

The periodical surveys were undertaken in different pigeon pea growing districts of Bihar, Jharkhand, Orissa \& West Bengal of Eastern India to collect the wilt of pigeon pea samples. The collections were made from nine districts of four states. Fifty five samples showing characteristic symptoms of pigeon pea wilt were collected for isolation of the pathogen (Table-1).

\section{Cultural and morphological variation}

Fifteen single spore isolates viz., Fu-9,Fu-10, Fu-27,Fu32, Fu-42, Fu-49, Fu-63, Fu-72, Fu-73,Fu-74,Fu-75,Fu84, Fu-86, Fu-87, Fu-97 were established and maintained on potato dextrose agar (PDA) were studied for their cultural and morphological characters by growing them on solid and liquid media. Seven days old culture (4 $\mathrm{mm}$ diameter disc) of each isolate was inoculated separately and incubated at $28 \pm 2^{\circ} \mathrm{C}$. In the study of solid medium, after eight days of the incubation period, fungal radial growth, colony characters, sporulation, pigmentation, size and septation in conidia were recorded. The size of conidia was measured by an ocular micrometre. In the liquid medium study, growth and sporulation were recorded after 15 days of the incubation period. The number of macro and micro conidia/ $\mathrm{ml}$ of spore suspension of $F$. udum was counted by haemo-

\section{cytometer.}

\section{Pathogenic variability}

A pathogenicity test of all the 15 isolates of $F$. udum was conducted on pigeon pea variety Bahar. The isolates were multiplied in autoclaved sand pigeon pea flour medium. The inoculums were mixed in sterilized soil@ 5 percent w/w. The surface-sterilized seeds of variety Bahar were sown @ 10 seeds /pots. A final observation on the plant stand and the number of wilted plants was recorded after 60 days after sowing. The isolates were categorized on the basis of wilt incidence into four groups as highly pathogenic $(>31 \%$ wilt incidence), moderately pathogenic (11-30\% wilt incidence), weakly pathogenic $(<10 \%$ wilt incidence).

\section{RESULTS AND DISCUSSION}

\section{Cultural and morphological variation}

Isolates differed in their cultural and morphological characteristics considerably on PDA. The maximum colony diameter $(70.0 \mathrm{~mm})$ was Fu-10 followed by Fu$49(59.3 \mathrm{~mm})$. The least colony diameter $(26.5 \mathrm{~mm})$ was of Fu- 87 followed by Fu- 63 isolate (Table-2). Fu-9, $10,49,84$ and 86 produced white mycelia with a serrated margin, fluffy growth with light and dark yellow pigmentation, while Isolates Fu-27, 32, 72, 73, 87 and 97 produced white mycelia color, serrated margin with partially appressed growth with light yellow to brown pigmentation. Isolates Fu-42, 63, 74 and 75 produced white mycelia, serrated margin with appressed growth with light and dark yellow pigmentation. Isolates Fu-10,

Table 1. List of $F$. udum isolates collected from different states of Eastern parts of India

\begin{tabular}{lllll}
\hline State & District & Village & Variety & Isolate designation \\
\hline Bihar & Muzaffarpur & Muraul & Bahar & Fu-9 \\
& Muzaffarpur & Dholi & Pusa 9 & Fu-10 \\
& Patna & Mohanchak & Bahar & Fu-27 \\
& Saran & Marwa & Land race & Fu-32 \\
& Samastipur & Musarigharari & Bahar & Fu-42 \\
& Bhagalpur & Banka & Land race & Fu-49 \\
West Bengal & Murshidabad & Lalbagh & Improve variety & Fu-63 \\
& Mushidabad & Dhamkal & Land race & Fu-72 \\
& Mursidabad & Nanakgram & Land race & Fu-73 \\
Orissa & Cuttak & Machgoa & Land race & Fu-74 \\
& Cuttak & Kugangh & Land race & Fu-75 \\
& Puri & Jatni & Land race & Fu-97 \\
Jharkhand & Garhwa & Tandwa & Improve variety & Fu-84 \\
& Garhwa & Jatta & Improve variety & Fu-86 \\
& Garhwa & Lakhiya & Improved variety & Fu-87
\end{tabular}


Kumar, S. / J. Appl. \& Nat. Sci. 13(4), 1305 - 1309 (2021)

Table 2. Variability of $F$. udum isolates based on cultural characteristics on PDA medium

\begin{tabular}{|c|c|c|c|c|}
\hline Isolate & Colony dia.* (mm) & Sporulation $^{* *}$ & Colony character & Pigmentation \\
\hline Fu-9 & 56.3 & ++ & $\begin{array}{l}\text { White mycelia color, serrated margin with } \\
\text { fluffy growth }\end{array}$ & Light yellow \\
\hline Fu-10 & 70.0 & ++++ & $\begin{array}{l}\text { White mycelia color, serrated margin with } \\
\text { fluffy growth }\end{array}$ & Dark yellow \\
\hline Fu-27 & 38.0 & ++++ & $\begin{array}{l}\text { White mycelia color, serrated margin with } \\
\text { partially appressed growth }\end{array}$ & Brown \\
\hline Fu-32 & 42.3 & ++++ & $\begin{array}{l}\text { White mycelia color, serrated margin with } \\
\text { partially appressed growth }\end{array}$ & Dark yellow \\
\hline Fu-42 & 56.3 & ++ & $\begin{array}{l}\text { White mycelia color, serrated margin with } \\
\text { appressed growth }\end{array}$ & Dark yellow \\
\hline Fu-49 & 59.3 & +++ & $\begin{array}{l}\text { White mycelia color, serrated margin with } \\
\text { fluffy growth }\end{array}$ & Light yellow \\
\hline Fu-63 & 32.3 & ++ & $\begin{array}{l}\text { White mycelia color, serrated margin with } \\
\text { appressed growth }\end{array}$ & Light yellow \\
\hline Fu-72 & 42.3 & +++ & $\begin{array}{l}\text { White mycelia color, serrated margin with } \\
\text { partially appressed growth }\end{array}$ & Dark yellow \\
\hline Fu-73 & 48.3 & ++ & $\begin{array}{l}\text { White mycelia color, serrated margin with } \\
\text { partially appressed growth }\end{array}$ & Dark yellow \\
\hline Fu-74 & 32.5 & ++++ & $\begin{array}{l}\text { White mycelia color, serrated margin with } \\
\text { appressed growth }\end{array}$ & Light yellow \\
\hline Fu-75 & 46.1 & +++ & $\begin{array}{l}\text { White mycelia color, serrated margin with } \\
\text { appressed growth }\end{array}$ & Light yellow \\
\hline Fu-97 & 39.3 & ++ & $\begin{array}{l}\text { White mycelia color, serrated margin with } \\
\text { partially appressed growth }\end{array}$ & Brown \\
\hline Fu-84 & 36.0 & ++ & $\begin{array}{l}\text { White mycelia color, serrated margin with } \\
\text { fluffy growth }\end{array}$ & Light yellow \\
\hline Fu-86 & 45.0 & +++ & $\begin{array}{l}\text { White mycelia color, serrated margin with } \\
\text { fluffy growth }\end{array}$ & Light yellow \\
\hline Fu-87 & 26.5 & ++ & $\begin{array}{l}\text { White mycelia color, serrated margin with } \\
\text { partially appressed growth }\end{array}$ & Brown \\
\hline \multicolumn{5}{|c|}{ C.D. $(P=0.05) \quad 0.82$} \\
\hline
\end{tabular}

*Average of three replications; * Sporulation categories: + Scanty; ++ Moderate; +++ Good; ++++ Abundant

27, 32 and 74 produced abundant sporulation while isolates $\mathrm{Fu}-49,72,75$ and 86 produced good sporulation. The remaining seven isolates viz., Fu-9,Fu-42, Fu -63, Fu-73,Fu-84, Fu-87 \& Fu-97 produced moderate sporulation. Maximum sporulation (2.6 X $10^{6}$ spores/ $\mathrm{ml}$ ) was produced by $\mathrm{Fu}-75$ isolate whereas least sporulation $\left(0.9 \times 10^{6}\right.$ spores $\left./ \mathrm{ml}\right)$ was produced by Fu-10 and Fu-97. The sporulation of remaining 12 isolates viz., Fu-9,Fu-27,Fu-32, Fu-42, Fu-49, Fu-63, Fu-72, Fu73,Fu-74,Fu-84, Fu-86, Fu-87 ranged between $1.0 \mathrm{X}$ $10^{6}-2.5 \times 10^{6}$ spores $/ \mathrm{ml}$.

The maximum dry mycelial weight of $\mathrm{Fu}-32$ isolate was $225.6 \mathrm{mg}$. It was followed by Fu-10 (205.6 mg), while the least mycelial dry weight of $90.3 \mathrm{mg}$ was produced by Fu-72 isolate. The mycelia weight of remaining 12 isolates viz., Fu-9, Fu-27,Fu-32, Fu-42, Fu-49, Fu-63, Fu-72, Fu-73,Fu-74,Fu-84, Fu-86, Fu-87 ranged between $112.3 \mathrm{mg}-198.0 \mathrm{mg}$. Morphological studies also revealed the variation of macro and micro conidia among 15 isolates of $F$. udum. The macro conidia were 2 to 4 , straight, spindle as well as sickle-shaped. The size of macro conidia ranged from 16.5-24.7 $\times$ 3.1$4.1 \mu \mathrm{m}$ in Fu-10 to $20.0-45.0 \times 2.5-5.0 \mu \mathrm{m}$ in Fu-97. The micro conidia were $0-1$ septate, hyaline, round to oval in shape. The size of micro conidia varies from 4.1$12.3 \times 2.0-4.1 \mu \mathrm{m}$ in $\mathrm{Fu}-42$ to $7.5-17.5 \times 2.5-5.0 \mu \mathrm{m}$ in Fu-87 (Table-3).

\section{Pathogenic variability}

Pathogenicity studies in 15 different isolates of $F$. udum also revealed significant variations in virulence. The wilt incidence among the different isolates ranged between 12.0 to $57.1 \%$. Four isolates (Fu- 10, Fu-27, Fu32 and $\mathrm{Fu}-49$ ) of $F$. udum expressed 35.1 to $57.4 \%$ wilt incidence after 60 days of sowing. Eleven isolates viz., Fu-9,Fu-42, Fu-63, Fu-72, Fu-73,Fu-74,Fu-75,Fu84, Fu-86, Fu-87, Fu-97were moderately pathogenic against susceptible variety and wilt incidence ranged from $12.6-27.0 \%$. (Table-3). Variation in cultural, morphological and pathogenic characteristics and sporulation among Isolates of Fusarium udum have been reported earlier (Joshi, 2010; Mahesh et al. 2010; Kumar 
Kumar, S. / J. Appl. \& Nat. Sci. 13(4), 1305 - 1309 (2021)

\begin{tabular}{|c|c|c|c|c|c|c|c|}
\hline \multirow{2}{*}{ Isolate } & \multirow{2}{*}{$\begin{array}{l}\text { Dry } \\
\text { myceli- } \\
\text { al } \\
\text { weight } \\
\text { (mg) }\end{array}$} & \multirow{2}{*}{$\begin{array}{l}\text { Spore } \\
\text { No. } \\
(\text { Million } \\
\mathrm{ml}^{-1} \text { ) }\end{array}$} & \multicolumn{2}{|c|}{ Macroconidia } & \multicolumn{2}{|c|}{ Microconidia } & \multirow{2}{*}{$\begin{array}{l}\text { Patho- } \\
\text { genicity }\end{array}$} \\
\hline & & & $\begin{array}{l}\text { Size }(\mu \mathrm{m}) \\
\text { Length \& width }\end{array}$ & Septation & $\begin{array}{l}\text { Size }(\mu \mathrm{m}) \\
\text { Length \& width }\end{array}$ & Septation & \\
\hline Fu-9 & 198.0 & 1.0 & $18.5-26.8 \times 2.1-6.2$ & 3-4 & $8.2-14.3 \times 2.1-4.1$ & $0-1$ & 14.3 \\
\hline Fu-10 & 205.6 & 0.9 & $16.5-24.7 \times 3.1-4.1$ & 3-4 & $6.2-12.4 \times 2.1-4.1$ & $0-1$ & 42.8 \\
\hline Fu-27 & 180.0 & 1.4 & $16.5-24.7 \times 2.1-6.2$ & $2-4$ & $6.2-12.4 \times 2.1-4.1$ & $0-1$ & 38.6 \\
\hline Fu-32 & 225.6 & 1.5 & $18.5-26.8 \times 3.1-4.1$ & $3-4$ & $10.3-14.3 \times 4.1-5.1$ & $0-1$ & 57.1 \\
\hline Fu-42 & 117.0 & 1.6 & $16.4-28.8 \times 2.0-4.1$ & $2-3$ & $4.1-12.3 \times 2.0-4.1$ & $0-1$ & 15.2 \\
\hline Fu-49 & 101.3 & 1.8 & $16.4-45.3 \times 4.1-6.1$ & $2-3$ & $10.3-14.4 \times 2.0-4.1$ & $0-1$ & 35.4 \\
\hline Fu-63 & 114.3 & 1.6 & $17.5-20.0 \times 2.5-5.0$ & $2-3$ & $2.5-15.0 \times 2.5-5.0$ & $0-1$ & 20.3 \\
\hline Fu-72 & 90.3 & 1.4 & $17.5-22.5 \times 2.5-5.0$ & $2-3$ & $5.0-15.0 \times 2.5-5.0$ & $0-1$ & 12.6 \\
\hline Fu-73 & 146.3 & 2.1 & $20.0-22.5 \times 2.5-5.0$ & $2-3$ & $2.5-17.5 \times 2.5-5.0$ & $0-1$ & 12.6 \\
\hline Fu-74 & 112.3 & 2.5 & $20.0-22.5 \times 2.5-5.0$ & $2-3$ & $5.0-17.5 \times 2.5-5.0$ & $0-1$ & 27.0 \\
\hline Fu-75 & 125.3 & 2.6 & $20.0-25.0 \times 2.5-5.0$ & $2-3$ & $5.0-17.5 \times 2.5-5.0$ & $0-1$ & 26.0 \\
\hline Fu-97 & 175.0 & 0.9 & $20.0-45.0 \times 2.5-5.0$ & $2-4$ & $2.5-17.5 \times 2.5-5.0$ & $0-1$ & 16.0 \\
\hline Fu-84 & 165.3 & 1.8 & $20.0-37.5 \times 2.5-5.0$ & $2-4$ & $5-17.5 \times 2.5-5.0$ & $0-1$ & 16.0 \\
\hline Fu-86 & 135.0 & 1.7 & $20.0-30.0 \times 2.5-5.0$ & $2-4$ & $5.0-15.0 \times 2.5-5.0$ & $0-1$ & 15.3 \\
\hline Fu-87 & 157.6 & 1.4 & $20.0-25.0 \times 2.5-5.0$ & $2-3$ & $7.5-17.5 \times 2.5-5.0$ & $0-1$ & 14.3 \\
\hline $\begin{array}{l}\text { C.D. } \\
(P=0.05)\end{array}$ & 9.08 & 0.21 & & & & & \\
\hline
\end{tabular}

${ }^{*}$ Average of three replications.

and Upadhyay, 2020) Mahesh et al. (2010) studied the colony character of 41 isolates of F.udum and reported three types of growth pattern on PDA viz., fluffy, partially appressed and appressed which support the present findings. Patel et al. (2011) also reported that different isolates of F.udum produced sporulation from 3.2 to $32.5 \times 10^{6}$ spores per ml. Kumar and Upadhyay (2009) observed typical wilt symptoms when pigeon pea seedlings (Bahar) were inoculated with 104 isolates of F.udum. The wilt incidence varied from 13.3\% to $100 \%$ after 45 days of inoculation. Joshi (2010) distinguished two isolates Nepalgunj and Sarlahi from $\mathrm{Ne}-$ pal on the basis of pathogenesis. Mesapogu et al. (2012) reported pathogenic variability among $F$. udum isolates collected from different geographical locations of India. All the isolates exhibited variable levels of virulence against a susceptible pigeonpea cultivar (T-21). Kumar and Upadhyay (2013) reported cultural, morphological and pathogenic variability among $15 \mathrm{~F}$. udum isolates collected from different geographical locations of Bihar. These isolates exhibited considerable variation in cultural and morphological characters. The isolates also exhibited variable levels of virulence against a susceptible pigeonpea cultivar (Bahar). Purohit et al. (2017) studied cultural characteristics, molecular variability and pathogenicity characteristics of 13 isolates of $F$. udum, collected from north, central and south regions of India. The isolates of $F$. udum showed variability in aerial and radial mycelium growth, colour of mycelia, substrate pigmentation, length and septation of macro and microconidia, which supports the current findings. A noticeable variation in the cultural, morphological and pathogenic characters was noticed in all the 15 isolates of F.udum. Variability in Fusarium isolates may be due to cultural characteristics, pathogenicity, vegetative compatibility, isozymes ds RNAs, nuclear DNA, polymorphism, mitochondrial DNA polymorphism and karyotype polymorphism as reported earlier (Kumar et al., 2007; Kumar and Upadhyay, 2020). Evaluation of more isolates of pigeon pea and further study on variations among them is required regularly to monitor any virulence shift.

\section{Conclusion}

The fifteen isolates of $F$. udum, collected from Bihar, Jharkhand, Orissa and West Bengal of India, showed variability in aerial and radial mycelium growth, colour , length, and septation of macro and microconidia. Pathogenesis and wilt progress among the different isolates on susceptible pigeonpea cultivars varied, with wilt incidence ranging between 12.0 to $57.1 \%$. Four isolates 
(Fu- 10, Fu-27, Fu-32 and Fu-49) of F. udum were highly pathogenic whereas eleven isolates viz., Fu9,Fu-42, Fu-63, Fu-72, Fu-73,Fu-74,Fu-75,Fu-84, Fu86, Fu-87, Fu-97were moderately pathogenic against susceptible variety. This study contributes to characterizing the vascular wilt of pigeonpea in eastern region of India.

\section{Conflict of interest}

The authors declare that they have no conflict of interest.

\section{REFERENCES}

1. Joshi, Sharda (2010). Pathogenic, variability in pigeonpea wilt pathogen Fusarium udum Butler in Nepal. Nepal Agric. Re. J., 4 \& 5, 64-65.

2. Kannaiyan, J., Nene, Y. L., \& Raju, T. N. (1985). Host specificity of pigeonpea wilt pathogen, Fusarium udum. Indian Phytopathology, 38(3), 553-554

3. Kannaiyan J, Nene, Y. L. \& Raju, T. N. (1985). Host specificity of pigeonpea wilt pathogen, Fusarium udum. Indian Phytopathology, 38(3), 553-554

4. Kumar Vinod, Chauhan, V. B. \& Srivastava, J. P. (2007) Pathogenic and biochemical variability in $F$. udum, causing pigeonpea wilt. Indian Phytopath., 60, 281-288

5. Kumar Sanjeev \& Upadhyay, J.P. (2009). Variability in isolates of Fusarium udum inciting pigeonpea wilt in Bihar. Int. con. on grain legumes: quality improvement, value addition and trade, IIPR, Kanpur, India, pp.295

6. Kumar Sanjeev \& Upadhyay, J.P. (2013). Cultural, morphological and pathogenic variability in isolates of Fusarium udum causing wilt of pigeonpea. J. Mycol. PI. Pathol. 43, 76-79

7. Kumar Sanjeev \& Upadhyay, J.P. (2014). Studies on cultural, morphological and pathogenic variability in isolates of Fusarium udum causing wilt of pigeonpea Indian Phytopath., 67, 55-58.

8. Kumar Sanjeev \& Upadhyay, J.P. (2020). Variability among the isolates of Fusarium udum (Butler) collected from Bihar, Jharkhand, Orissa and West Bengal districts of eastern India. J. Mycol. PI. Pathol., 50, 289-298

9. Mahesh M, Saifulla M, Prasad P.S. \& Sreenivasa S. (2010).Studies on cultural variability of Fusarium udum isolates in India. I. J. S. N.2, 219-225.

10. Mesapogu S, Achala, Babu B. K, Reddy S.S, Sangeeta S \& Arora K. D. (2012). Genetic diversity and pathogenic variability among Indian isolates of Fusarium udum infecting pigeonpea. Int. Res. J. of Agri. Sci. and Soil. Sci., 2, 051-057

11. Nene Y.L, Sheeila V.K. \& Sharma S.B. (1996). A world list of chickpea and pigeonpea pathogens. Fifth Edition, ICRISAT, Patancheru, Andhra Pradesh, India, pp. 19-20.

12. Nene Y. L, Kannaiyan. J, Haware, M.P \& Reddy M.V. (1979). Review of work done at ICRISAT on soil borne diseases of pigeonpea and chickpea. In :Proceedings of the Consultant Group Discussion on the Resistance to Soil borne Diseases of Legumes, ICRISAT, Patancheru, Andhra Pradesh, India, pp.3

13. Patel S.I., Patel, R.L., Desai, A.G. \& Patel, D.S. (2011). Morphological, cultural and pathogenic variability among Fusarium udum and root dip inoculation technique for screening pigeonpea germplasm. J. Mycol. PI. Pathol., 41, 2011

14. Patel S. I. \& Patel B. M. (2012). Pigeonpea wilt and its management : A review. Agres - An International EJournal , 1.4:400-413

15. Purohit A., Ganguly S., Ghosh G., Chaudhuri R.K., Datta S. \& Chakraborti, D. (2017).Variability among isolates of Fusarium udum and the effect on progression of wilt in pigeonpea. Euro. J. of Pl. Patho., 149(1), 73-87

16. Reddy, M.V., Sharma S.B. \& Nene Y.L. (1990). Pigeonpea: Disease management. In :The Pigeonpea (Eds. Y. L. Nene, S. D. Hall and V. K. Sheila), CAB International, Wallingford, U.K., 303-347 pp.

17. Saxena R.K, Saxena, K.B, Kumar R.V, Hoisington D.A \& Varshney R.K. (2010). Simple sequence repeat-based diversity in elite pigeonpea genotypes for developing mapping populations to map resistance to Fusarium wilt and sterility mosaic disease. Plant Breed., 129, 135-14. 